\title{
KEBERADAAN Vibrio parahaemolyticus PATOGENIK PADA UDANG TAMBAK YANG BERASAL DARI PANTAI UTARA JAWA
}

\section{Presence of Potentially Human Pathogenic Vibrio parahaemolyticus of Fresh Shrimp in Ponds of The Northern Coast of Java}

\author{
Arifah Kusmarwati*, Irma Hermana, Yusma Yennie dan Singgih Wibowo \\ Pusat Penelitian dan Pengembangan Daya Saing Produk dan Bioteknologi Kelautan dan Perikanan, \\ JI.K.S. Tubun Petamburan VI, Jakarta Pusat, Indonesia \\ Korespondensi Penulis: akusmarwati@gmail.com \\ Diterima : 10 Maret 2016; Disetujui: 19 Mei 2016
}

\begin{abstract}
ABSTRAK
Penelitian ini bertujuan untuk memberikan informasi cemaran Vibrio parahaemolyticus patogenik pada udang tambak. Pengambilan sampel udang segar vaname dari tambak dilakukan pada musim hujan dan musim kemarau di wilayah Pantai Utara Jawa dengan metode purposive random sampling. Sebanyak 103 sampel (masing-masing 33 sampel dari wilayah Jawa Barat, 14 sampel dari wilayah Jawa Tengah dan 56 sampel dari wilayah Jawa Timur) telah diestimasi kandungan $V$. parahaemolyticus total dan patogenik menggunakan metode kultivasi pada medium CHROMagar ${ }^{\mathrm{TM}}$ Vibrio (CV) dan metode polymerase chain reaction (PCR) melalui amplifikasi gen toxR untuk total $V$. parahaemolyticus, serta gen $t d h$ dan trh untuk $V$. parahaemolyticus patogen. Hasil analisis menunjukkan bahwa dari 103 sampel, 91 sampel bersifat tipikal pada medium CHROM agar ${ }^{\top \mathrm{M}}$ Vibrio (CV). Selanjutnya dari 91 sampel tipikal tersebut, $62(63,27 \%)$ sampel menunjukkan hasil positif untuk $V$. parahaemolyticus dengan metode PCR. Sementara dari 31 sampel positif $V$. parahaemolyticus yang berasal dari Jawa Timur ditemukan 2 sampel $(3,23 \%)$ positif mengandung gen $t d h$, 1 sampel $(1,61 \%)$ positif mengandung gen $t d h$ dan trh, dan 1 sampel $(1,61 \%)$ positif mengandung gen trh.
\end{abstract}

KATAKUNCl: Vibrio parahaemolyticus, udang, Pantai Utara Jawa

\section{ABSTRACT}

Research was conducted to give information about pathogenic Vibrio parahaemolyticus contamination on shrimp. Sampling of fresh shrimps from the ponds was conducted in rainy and dry season in the Northern Coast of Java with purposive randomize sampling method. The level of total and pathogenic $\underline{\mathrm{V}}$. parahaemolyticus were estimated in 103 samples (each 33 samples of West Java, 14 samples of Central Java, and 56 samples of East Java) using CHROM agar ${ }^{T M}$ Vibrio $(C V)$ medium and polymerase chain reaction (PCR) methods by amplification of tox $\mathrm{R}$ gene for total $\underline{V}$. parahaemolyticus, tdh and trh genes for pathogenic $\underline{V}$. parahaemolyticus. The result showed that out of 103 samples, 91 samples were a typical on chromogenic agar Vibrio. Out of 91 typical samples, 62 (63.27\%) samples gave positive results for total $\underline{V}$. parahaemolyticus. Out of 31 positive samples $\underline{V}$. parahaemolyticus from East Java, 2 samples (3.23\%) positively contained the tdh gen, 1 sample (1.61\%) positively contained the tdh and trh gen, and 1 sample $(1.61 \%)$ positively contained the trh gen.

KEYWORDS: Vibrio parahaemolyticus, shrimp, Northen Java Coast

\section{PENDAHULUAN}

Vibrio parahaemolyticus (V. parahaemolyticus) merupakan bakteri patogen bagi manusia yang cukup penting, karena berasosiasi dengan gastroenteritis dan infeksi foodborne pada manusia terutama yang disebabkan oleh konsumsi produk-produk seafood termasuk udang mentah/dimasak setengah matang atau akibat terkontaminasi. Beberapa kasus dilaporkan bahwa terjadinya foodborne atau waterborne disebabkan oleh spesies vibrio lain seperti V. mimicus dan V. alginolyticus (Centre for Health Protection, 2010; Merward, El-Ghareeb \& Taisir, 2011; Shah \& Deokule, 2006; Tiruvayipati et al., 2013; Yoder 
et al., 2008). Bakteri ini menjadi penyebab kasus septisemia dan diare di berbagai wilayah Asia Tenggara (Merward, et al.; Thomspon, Lida \& Swings, 2004).

Beberapa kasus keracunan pangan akibat kontaminasi mikroba menyebabkan kejadian luar biasa (KLB), akan tetapi sangat sedikit informasi terkait dengan kasus-kasus tersebut di Indonesia. Beberapa kasus yang pernah dilaporkan antara lain ditemukannya penyakit gastroenteritis akut dan wabah diare serupa kolera akibat kontaminasi V. parahaemolyticus (Dewanti-Hariyadi, Suliantari, Nuraida \& Fardiaz, 2002; Lesmana et al., 2001). Sementara dari negara lain, KLB atau kasus seafood borne gastroenteritis $V$. parahaemolyticus yang disebabkan oleh sashimi dan sushi pernah dilaporkan terjadi di Jepang dan India (FDA, 2000; Nelapati \& Krishnaiah, 2010). Dosis infeksi bakteri adalah $10^{5}-$ $10^{7} \mathrm{cfu} / \mathrm{g}$ (Centre for Health Protection, 2010), namun FDA menyebutkan $10^{5}-10^{9} \mathrm{cfu} / \mathrm{g}$ (FDA, 2000).

Strain $V$. parahaemolyticus yang dapat menimbulkan penyakit pada umumnya berhubungan dengan keberadaan faktor virulensi thermostable direct hemolysin (TDH) dan thermostable direct hemolysin related hemolysin (TRH) (Broberg, Calder \& Orth, 2011; Nishibuchi \& Kaper, 1995). Thermostable direct hemolysin (TDH) dikenal sebagai faktor virulensi karena aktivitas $\beta$ hemolisisnya yang dapat melisis sel darah merah pada agar Wagatsuma (fenomena Kanagawa positif /KP+) sehingga mengakibatkan gastroenteritis dan kematian sel (Bhunia, 2008; Nishibuchi \& Kaper, 1995). Sementara keberadaan $\mathrm{TRH}$ dikaitkan dengan fenomena Kanagawa negatif (Vieira, Costa, Menezes, \& Maggioni, 2011).

Udang merupakan salah satu komoditas utama ekspor perikanan Indonesia dengan total produksi tahun 2014 mencapai 645 ribu ton, sedangkan ekspor terbesar adalah ke Amerika Serikat senilai US\$ 938 juta dengan total volume 77 ribu ton (Katadata KKP, 2016). Beberapa informasi dari Dinas Kelautan dan Perikanan di Indonesia menyebutkan sejumlah besar tambak udang intensif di wilayah Pantai Utara Jawa merupakan penyuplai udang untuk tujuan ekspor. Namun kontaminasi bakteri patogen pada produk udang menjadi permasalahan serius yang berujung pada penolakan ekspor.

Pada tahun 2005, 2007, dan 2009 terjadi beberapa kasus penolakan ekspor udang vaname oleh Uni Eropa karena kontaminasi $V$. parahaemolyticus yang berasal dari produk udang beku dan sushi ebi. Kemudian pada tahun 2009 dan 2010 terjadi penolakan ekspor ikan Indonesia oleh negara Cina karena alasan yang sama (Sunorita \& Tjarsono, 2014). Penolakan ekspor produk perikanan Indonesia oleh negara Taiwan juga terjadi akibat keberadaan $V$. parahaemolyticus patogenik (Wong, Chen, Liu, \& Liu, 1999).

Beberapa penelitian tentang prevalensi V. parahaemolyticus pada produk perikanan maupun lingkungan di Indonesia telah dilakukan, namun informasi yang diberikan masih sangat terbatas. Dilaporkan bahwa pada sampel kerang dan udang yang berasal dari pasar lokal, perairan, dan tambak tradisional dan intensif mengandung $V$. parahaemolyticus (Felix, Nugroho, Silalahi \& Octavia, 2011; Marlina et al., 2007; Yennie, Hariyadi \& Poernomo, 2015; Zulkifli et al., 2009). Berdasarkan penjelasan di atas maka penelitian mengenai keberadaan $V$. parahaemolyticus patogenik pada udang tambak menjadi sangat diperlukan.

\section{BAHAN DAN METODE}

\section{Bahan}

Sampel udang vaname diperoleh dari tambak udang intensif dan semi intensif di wilayah Pantai Utara Jawa. Sampel udang dari tambak intensif diambil dari tambak yang berlokasi di Kabupaten Indramayu, Karawang, Brebes, Sidoarjo, dan Lamongan, sedangkan tambak semi intensif berlokasi di Kabupaten Tuban. Sampel yang berasal dari Kabupaten Indramayu dan Karawang seluruhnya berasal dari satu area budidaya tambak masingmasing sebanyak 16 dan 22 petak tambak yang berlokasi di Kecamatan Patrol dan Kecamatan Cilebar. Sampel udang dari Kabupaten Brebes berasal dari Kecamatan Brebes yaitu dari desa Pulosari (4 petak), Randusanga (3 petak), Limbangan Wetan (2 petak) dan Limbangan Kulon (2 petak). Sampel udang dari Kabupaten Sidoarjo berasal dari Kecamatan Paciran (7 petak) dan Kecamatan Sidoarjo (3 petak). Sampel udang yang berasal dari Kabupaten Lamongan berasal dari Kecamatan Brondong (15 petak) dan Kecamatan Lamongan (7 petak), sementara sampel udang dari Kabupaten Tuban berasal dari Kecamatan Tuban yaitu dari Desa Tuban (11 petak), Desa Jenu (7 petak),dan Desa Gesik Harjo (4 petak). Jenis udang yang diambil adalah udang vaname siap panen dengan umur pemeliharaan 53-108 hari.

\section{Metode}

\section{Teknik pengumpulan sampel}

Pengambilan sampel udang segar vaname dari tambak dilakukan pada musim hujan dan musim kemarau di wilayah Pantai Utara Jawa dengan metode purposive random sampling. Adapun waktu pengambilan sampel disesuaikan dengan waktu panen 
tambak berdasarkan informasi dari penyuluh Dinas Kelautan dan Perikanan setempat. Pengambilan sampel udang pada musim hujan dilakukan 2 kali yaitu pada bulan Februari dan Maret 2015, sedangkan pengambilan sampel udang pada musim kemarau dilakukan 3 kali yaitu pada bulan Agustus, September, dan Oktober 2015. Ukuran udang yang diambil antara 58-160. Pada setiap petak tambak diambil sebanyak 4 titik sampel dengan berat sampel pada setiap petak sekitar 500 gram. Sampel yang berasal dari Kabupaten Indramayu, Karawang dan Brebes dimasukkan ke dalam plastik steril secara aseptis kemudian ditempatkan dalam coolbox yang berisi es curah. Selanjutnya sampel dibawa ke laboratorium untuk dilakukan analisis. Sementara sampel yang berasal dari Jawa Timur diambil secara aseptis dan dimasukkan ke dalam plastik steril, kemudian dibekukan terlebih dahulu sebelum dibawa ke laboratorium untuk selanjutnya dilakukan analisis.

\section{Isolasi dan identifikasi $V$. parahaemolyticus dengan Chrom agar Vibrio (BSN, 2006)}

Analisis sampel bakteri diawali dengan enrichment (pengkayaan), isolasi dan identifikasi bakteri menggunakan media selektif chrom agar vibrio yang dilanjutkan dengan konfirmasi $V$. parahaemolyticus yang bersifat patogen dan non patogen dengan menggunakan metode polymerase chain reaction (PCR).

Isolasi $V$. parahaemolyticus dilakukan menurut metode BSN (2006) yang diawali dengan proses pengkayaan kultur dengan media alkaline pepton water (APW) enrichment broth (APW dengan penambahan $3 \% \mathrm{NaCl}$ ). Selanjutnya dilakukan perhitungan konsentrasi bakteri dengan metode MPN (USFDA, 2015). Pengujian MPN dilakukan dengan menggunakan 3 seri tabung masing-masing sebanyak 3 ulangan pada media APW enrichment broth. Setiap kultur pada tabung yang menunjukkan adanya kekeruhan digores pada media chrom agar vibrio dan diinkubasi pada suhu $37^{\circ} \mathrm{C}$ selama $18-24$ jam. Koloni yang tumbuh pada media selektif chrom agar vibrio dan berwarna ungu kemerahan merupakan presumtif $V$. parahaemolyticus. Koloni tipikal V. parahaemolyticus kemudian diinokulasikan pada media agar miring Tryptic Soy Agar (TSA, Oxoid, England) ditambah 2,5\% NaCl untuk selanjutnya dilakukan konfirmasi $V$. parahaemolyticus menggunakan metode PCR.

\section{Konfirmasi $V$. parahaemolyticus dan $V$. parahaemolyticus patogenik dengan PCR}

Konfirmasi adanya V. parahaemolyticus non patogenik pada sampel didasarkan pada keberadaan gen spesifik toxR, sementara konfirmasi $V$. parahaemolyticus patogenik didasarkan pada gen spesifik tdh dan trh yang dilakukan menggunakan metode polymerase chain reaction (PCR). Pada tahap awal dilakukan ekstraksi DNA genomik, dilanjutkan dengan amplifikasi gen dengan menggunakan sepasang primer spesifik gen penyandi toxR untuk $V$. parahaemolyticus non patogen serta menggunakan sepasang primer spesifik gen penyandi $t d h$ dan $t r h$ untuk V. parahaemolyticus patogenik, kemudian dilanjutkan dengan elektroforesis gel.

Ekstraksi DNA genomik dilakukan dengan kit ekstraksi DNA menggunakan protokol ekstraksi DNA dari TIANamp (Tiangen Biotech, Beijing). Amplifikasi untuk konfirmasi adanya $V$. parahaemolyticus dilakukan dengan menggunakan sepasang primer spesifik gen penyandi toxR pada pita $368 \mathrm{bp}$ (Tabel 1).

Amplifikasi untuk mengkonfirmasi $V$. parahaemolyticus patogenik dilakukan dengan menggunakan sepasang primer spesifik gen penyandi tdh pada pita 199 bp dan sepasang primer spesifik gen penyandi trh pada pita $250 \mathrm{bp}$ (Tabel 1). Adapun reaksi PCR dilakukan menggunakan campuran reaktan yang masing-masing mengandung 1 primer forward dan reverse dan Taq Green Master Mix dengan

Tabel 1. Primer Oligonukleotida yang digunakan dalam studi

Table 1. Oligonucleotide primers used in the study

\begin{tabular}{|c|c|c|c|c|}
\hline $\begin{array}{c}\text { Primer/ } \\
\text { Primer }\end{array}$ & $\begin{array}{l}\text { Gen Target/ } \\
\text { Target Gen }\end{array}$ & $\begin{array}{l}\text { Sekuen Primer }\left(5^{\prime}-3^{\prime}\right) / \\
\text { Primer Sequence }\left(5^{\prime}-3^{\prime}\right)\end{array}$ & $\begin{array}{l}\text { Ukuran Fragmen (bp)/ } \\
\text { Fragment Size (bp) }\end{array}$ & $\begin{array}{l}\text { Referensi/ } \\
\text { Reference }\end{array}$ \\
\hline tox R-F & tox $\mathrm{R}$ & GTCTTCTGACGCAATCGTTG & 368 & Kim et al., 1999 \\
\hline tox $\mathrm{R}-\mathrm{R}$ & tox $\mathrm{R}$ & ATACGAGTGGTTGCTGTCATG & 368 & Kim et al., 1999 \\
\hline$t d h-\mathrm{F}$ & $t d h$ & ССАСТАССАСТСТСАТАТGС & 199 & Tada et al., 1992 \\
\hline$t d h-\mathrm{R}$ & $t d h$ & GGTCTAAATGGCTGACATC & 199 & Tada et al., 1992 \\
\hline trh-R & trh & GGCTCAAAATGGTTAAGCG & 250 & Tada et al., 1992 \\
\hline trh $-\mathrm{F}$ & trh & CATTTCCGCTCTCATATGC & 250 & Tada et al., 1992 \\
\hline
\end{tabular}


Tabel 2. Kondisi siklus pada ketiga pasangan primer

Table 2. Cycling conditions used for three sets of primers

\begin{tabular}{|c|c|c|c|c|}
\hline No & Tahapan/Step & tox $\mathrm{R} /$ tox $\mathrm{R}$ & $t d h / t d h$ & trh/trh \\
\hline 1. & Predenatura & $96^{\circ} \mathrm{C} /$ & $96{ }^{\circ} \mathrm{C} / 5$ & 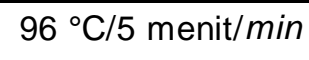 \\
\hline 2. & Denaturasi final/Final denaturation & $94{ }^{\circ} \mathrm{C} / 1 \mathrm{n}$ & $94{ }^{\circ} \mathrm{C} / 1 \mathrm{n}$ & $/ \min$ \\
\hline 3. & Penempelan primer/Annealing & $63^{\circ} \mathrm{C} / 1,5$ & $55^{\circ} \mathrm{C} / 1 \mathrm{menit} / \mathrm{min}$ & $55^{\circ} \mathrm{C} / 1$ \\
\hline 4. & Pemanjangan awal//nitial extension & $72^{\circ} \mathrm{C} / 1,5 \mathrm{menit} / \mathrm{min}$ & $72^{\circ} \mathrm{C} / 1 \mathrm{menit} / \min$ & $72^{\circ} \mathrm{C} / 1 \mathrm{menit} / \mathrm{min}$ \\
\hline 5. & Pemanjangan final/Final extension & $72{ }^{\circ} \mathrm{C} / 7 \mathrm{~m}$ & $72^{\circ} \mathrm{C} / 7$ menit $/ \min$ & $72^{\circ} \mathrm{C} / 7 \mathrm{r}$ \\
\hline
\end{tabular}

protokol PCR yang mengacu pada Yennie et al. (2015) dan Zulkifli et al. (2009). Kondisi siklus pada ketiga pasangan primair sesuai dengan Tabel 2 .

Elektroforesis gel dilakukan menurut Zulkifli et al. (2009) dengan sedikit modifikasi. Sebanyak $5 \mu \mathrm{l}$ produk PCR dimasukkan ke dalam gel agarose $2 \%$ menggunakan bufer TBE1X. Alat dijalankan pada voltase 70 Volt dan arus 35 Ampere selama 35 menit. Selanjutnya pada gel yang terbentuk dilakukan pewarnaan menggunakan etidium bromide $0,5 \mu \mathrm{g} / \mathrm{ml}$. Identifikasi menggunakan kontrol positif V. parahaemolyticus ATCC43996 untuk gen tdh dan V. parahaemolyticus AQ4037 untuk gen trh.

\section{HASIL DAN BAHASAN}

Dari 103 sampel udang vaname segar yang berasal dari tambak-tambak semi intensif/intensif wilayah Pantai Utara Jawa dan telah diuji menggunakan CHROMagar $^{\mathrm{TM}}$ Vibrio, terdapat 91 sampel tipikal V. parahaemolyticus. Selanjutnya dari 91 sampel tipikal, setelah dikonfirmasi dengan PCR menggunakan primer gen toxR, terdeteksi 62 sampel positif $V$. parahaemolyticus (Tabel 3). Hal ini serupa dengan studi lain yang melaporkan bahwa sekitar 50$70 \%$ produk udang/seafood mengandung V. parahaemolyticus (Adebayo et al., 2011; Annick, Alain \& Fournier, 2002; Linda \& Asim, 2006; Nelapati \& Krishnaiah, 2010; Yennie et al., 2015; Zulkifli et al., 2009). Seleksi isolat vibrio didasarkan pada keberadaan koloni yang berwarna ungu pada media kromogenik vibrio yaitu CHROM agar ${ }^{\mathrm{TM}}$ Vibrio.

Media tersebut dikembangkan oleh Hara-Kudo et al. (2003) dan mengandung substrat kromogenik (beta galaktosidase) yang mengandung gula fermentasi untuk mendeteksi munculnya warna ungu pada koloni V. parahaemolyticus (Zulkifli et al., 2009). Contoh deteksi $V$. parahaemolyticus menggunakan primer gen toxR disajikan pada Gambar 1 yaitu dari 11 sampel udang yang dianalisa terdapat 10 sampel yang menunjukkan hasil positif (memiliki band).
Pada penelitian ini, V. parahaemolyticus telah terdeteksi pada hampir semua sampel udang (62 dari 103 sampel) yang berasal dari beberapa lokasi tambak di sepanjang Pantai Utara Jawa mulai dari Indramayu, Brebes hingga Tuban, sebagaimana disajikan pada Tabel 4. Insidensi $V$. parahaemolyticus pada penelitian ini cukup tinggi $(60,2 \%)$. Hasil ini relatif lebih tinggi dibandingkan dengan hasil penelitian sebelumnya. Zulkifli et al. (2009) menyebutkan prevalensi $V$. parahaemolyticus pada sampel kerang yang berasal dari Padang, Sumatera Barat $(\mathrm{N}=50)$ sebesar $50 \%$. Sementara Yennie et al. (2015) melaporkan prevalensi $V$. parahaemolyticus dari sampel udang yang berasal dari tambak tradisional dan intensif di Indramayu berturut-turut sebesar $50 \%$ dan $18,75 \%$. Pada penelitian ini prevalensi $V$. parahaemolyticus pada sampel udang yang berada di lokasi yang sama mencapai $92,3 \%$. Prevalensi V. parahaemolyticus pada sampel ikan di Kolkata India juga relatif lebih tinggi. Pal dan Das (2010) menyebutkan dari 90 sampel ikan yang diperoleh dari pasar ikan lokal di Kolkata India 60 di antaranya positif mengandung V. parahaemolyticus. Dua puluh satu dari 60 (35\%) sampel tersebut positif mengandung gen $t d h$, dan 1 dari $60(1,7 \%)$ sampel membawa gen trh. Kondisi ini bisa menjadi penyebab terjadinya diare pada orang yang mengkonsumsi ikan asal Kolkata yang terkontaminasi $V$. parahaemolyticus. Namun beberapa peneliti lain menyebutkan adanya prevalensi $V$. parahaemolyticus yang lebih rendah. Yang et al. (2008) mengemukakan prevalensi $V$. parahaemolyticus pada sampel seafood asal Cina sebesar 19,0\%. Sementara Adebayo et al. (2011) melaporkan derajat infeksi seafood oleh $\mathrm{V}$. parahaemolyticus sebesar $18,9 \%$, yakni $20 \%$ berasal dari periwinkle, kulit dan usus ikan, $10 \%$ dari crayfish, aquatic snail dan sampel air.

Caburlotto et al. (2016) melaporkan telah terdeteksi 40 sampel positif $(28 \%)$ V. parahaemolyticus yang berasal dari sampel udang $(n=143)$ yang biasa dikonsumsi di Italia. Adapun prevalensinya sebanyak 


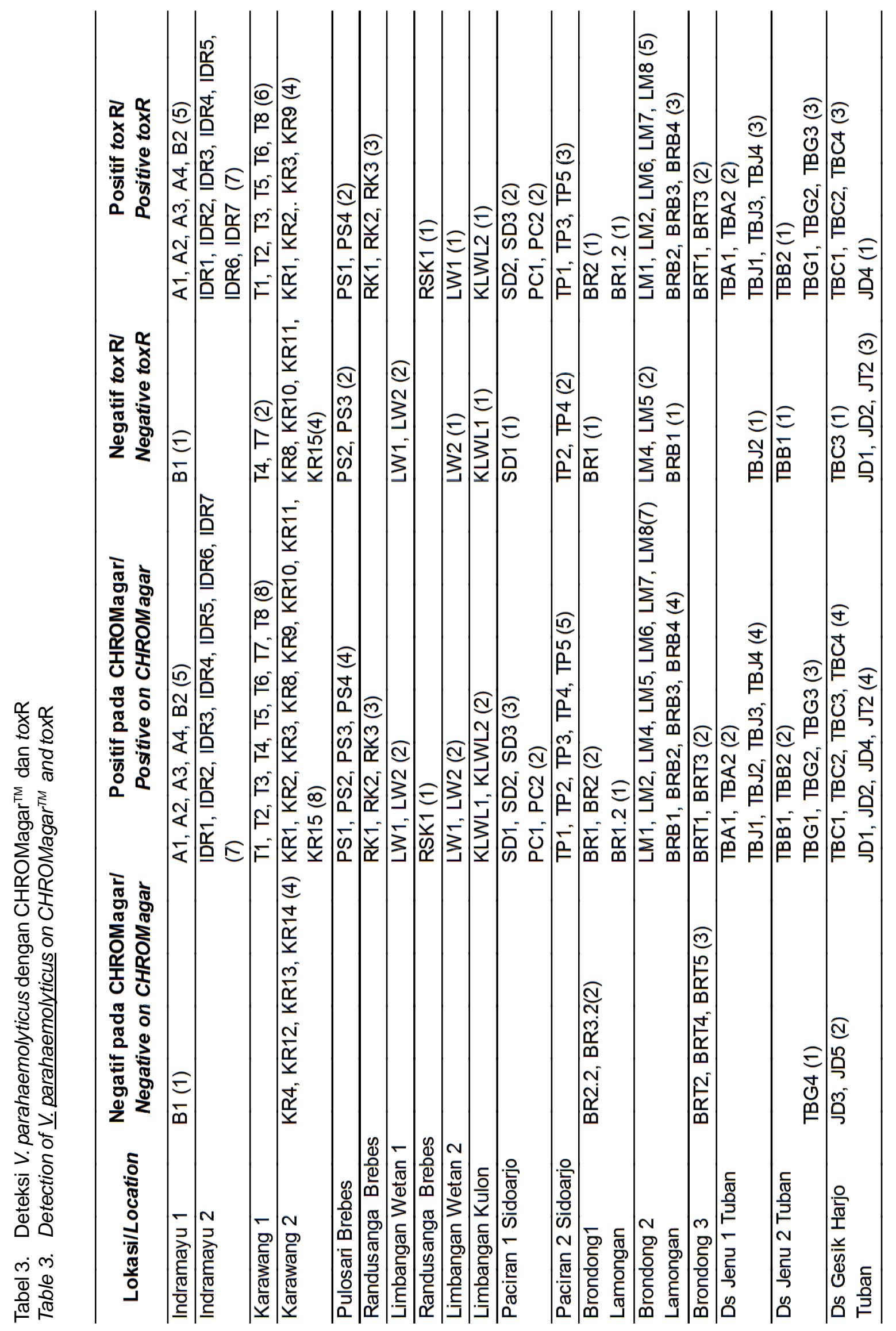




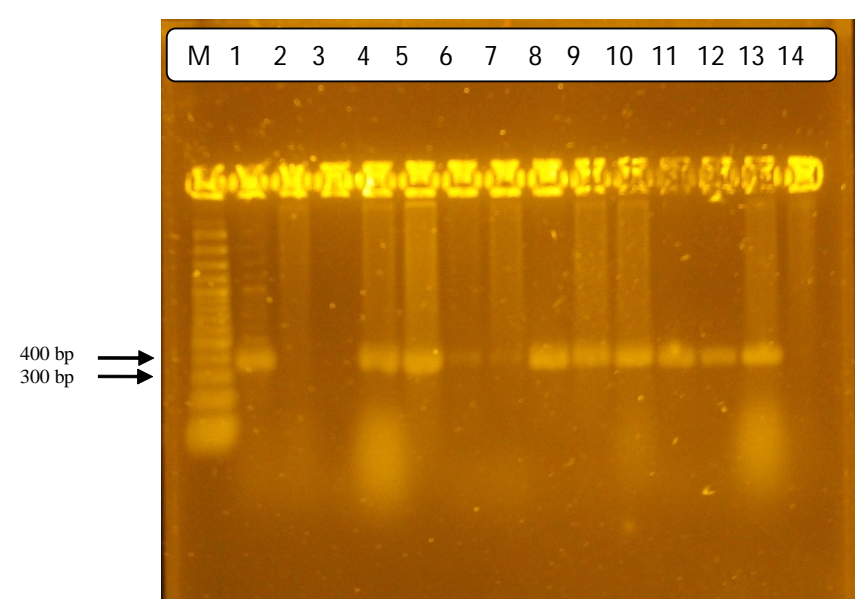

Gambar 1. Contoh deteksi gen toxR pada $V$. parahaemolyticus M. $1 \mathrm{~kb}$ marker, 1 . Kontrol positif ( $V$. parahaemolyticus), 2. Kontrol negatif (Klebsiella sp.), 3. Kontrol negatif (water), 4-14. Sampel (sampel 4-13 menunjukkan hasil positif)

Figure 1. Example of toxR gene detection in $\underline{V}$. parahaemolyticus $M .1 \mathrm{~kb}$ ladder, 1. Positive control ( $\underline{V}$. parahaemolyticus), 2. Negative control (Klebsiella sp.), 3. Negative control (water), 4-14. Samples (Sample 4-13 were shown as positive result)

$41 \%$ berasal dari produk dingin dan $8 \%$ berasal dari produk beku. Prevalensi dan derajat kontaminasi V. parahaemolyticus tertinggi terdeteksi di Crangon, Italia (prevalensi 58\% dan konsentrasi $3400 \mathrm{MPN} / \mathrm{g}$ ) dan yang berasal dari Laut Adriatik Utara (35\%) dengan sampel dari Danau Venetia Utara yang mencapai 1375 MPN/g. Sementara hasil analisis genetis menunjukkan bahwa tidak ditemukan adanya gen $t d h$, namun terdapat 3 isolat yang mengandung gen trh dan gen T3SS2 $\alpha$. Hasil ini memperlihatkan pentingnya mempertimbangkan penggunaan marker gen target virulen baru (T3SS2 $\alpha$ ) dalam konfirmasi keberadaan faktor virulen pada $V$. parahaemolyticus selain menggunakan faktor virulen klasik.

Tabel 4. Insidensi $V$. parahaemolyticus pada udang vaname dari berbagai lokasi tambak Table 4. Incidence of $\underline{\underline{V}}$ parahaemolyticus in vaname shrimp obtained from different locations of ponds

\begin{tabular}{lccc}
\hline \multicolumn{1}{c}{ Lokasi/ } & $\begin{array}{c}\text { Jumlah Sampel yang Diuji/ } \\
\text { No. of Samples Examined }\end{array}$ & V. parahaemolyticus & (\%) \\
\hline Indramayu 1 & 6 & 5 & 83.3 \\
Indramayu 2 & 7 & 7 & 100.0 \\
Karawang 1 & 8 & 6 & 75.0 \\
Karawang 2 & 12 & 4 & 33.3 \\
Paciran 1 Sidoarjo & 5 & 4 & 80.0 \\
Paciran 2 Sidoarjo & 5 & 3 & 60.0 \\
Brondong 1 Lamongan & 5 & 2 & 40.0 \\
Brondong 2 Lamongan & 11 & 8 & 72.7 \\
Brondong 3 Lamongan & 5 & 1 & 20.0 \\
Desa Jenu 1 Tuban & 6 & 5 & 83.3 \\
Desa Jenu 2 Tuban & 6 & 4 & 66.7 \\
Desa Gesik Harjo Tuban & 10 & 4 & 40.0 \\
Pulosari Brebes & 4 & 2 & 50.0 \\
Randusanga Brebes 1 & 4 & 4 & 100.0 \\
Randusanga Brebes 2 & 1 & 1 & 100.0 \\
Limbangan Wetan 1 & 4 & 0 & 0.0 \\
Limbangan Wetan 2 & 2 & 1 & 50.0 \\
Limbangan Kulon & 2 & 1 & 50.0 \\
\hline Jumlah total (\% positif)/ & 103 & 62 & 60.2 \\
Total number(\% positive) & & &
\end{tabular}


Tingginya insidensi $V$. parahaemolyticus pada udang disebabkan karena $V$. parahaemolyticus merupakan flora normal di lingkungan perairan payau, sebagaimana dikemukakan oleh DePaola, Kaysner, Bowers dan Cook (2000) dan Ceccarelli, Hasan, Huq dan Colwell (2013) bahwa V. parahaemolyticus merupakan flora normal di lingkungan perairan payau dan lingkungan pantai, merupakan biota alami pada kerang-kerangan serta menjadi salah satu spesies Vibrio spp. yang bersifat patogen terhadap komoditas udang maupun pada manusia. Vibrio sp. dapat terjadi secara alami dalam lingkungan perairan dan merupakan bakteri yang paling sering terjadi di lingkungan budidaya udang (Abu \& Egenonu, 2008; Chitov, Wongdao, Thatum, Puprae \& Sisuwan, 2009; DePaola et al., 2000; Newton, Kendall, Vugia, Henao \& Mahon, 2012). Namun terkadang para turis internasional juga ikut bertanggung jawab menyebarkan infeksi ini dari satu negara ke negara lain sebagaimana dikemukakan oleh Pal dan Das (2010). Sementara penggandaan $V$. parahaemolyticus berkaitan dengan suhu air dan musim. Lebih lanjut Chitov et al. melaporkan tingginya kandungan Vibrio spp. pada kerang yang melebihi $10^{4} \mathrm{cfu} / \mathrm{g}$ akan berpotensi membahayakan terlebih jika strain yang mengkontaminasi produk merupakan strain yang bersifat patogen. Keberadaan strain Vibrio patogenik tersebut akan memberi dampak keamanan bagi produk yang dimasak atau siap saji jika bakteri tersebut survive karena proses pemasakan yang kurang sempurna atau menjadi sumber rekontaminasi setelah proses pengolahan pangan.

Indonesia dikenal sebagai wilayah tropis yang sangat berpotensi menyebabkan tingginya keberadaan $V$. parahaemolyticus. Hal ini dimungkinkan karena tingginya suhu air laut (25-35 $\left.{ }^{\circ} \mathrm{C}\right)$ yang menyebabkan keberadaan $V$. parahaemolyticus yang selalu terdeteksi dan terdistribusi sepanjang tahun. Suhu perairan laut yang tinggi merupakan faktor utama yang berkontribusi terhadap tingginya persentase $V$. parahaemolyticus (Zulkifli et al., 2009). Disebutkan bahwa sebagian besar wilayah beriklim tropis seperti Asia Tenggara memiliki potensi besar akan keberadaan V. parahaemolyticus, yakni dengan persentase sekitar 20-70\% (Ronald \& Santos, 2001; Wong et al., 1999).

Pada penelitian ini, sejumlah besar isolat V. parahaemolyticus telah berhasil diisolasi selama bulan Februari (5 isolat), Maret (28 isolat) dan Agustus (14 isolat) ketika suhu air perairan tambak berada pada kisaran $27-29^{\circ} \mathrm{C}$ (Tabel 5). Insidensi $V$. parahaemolyticus pada musim hujan cenderung lebih tinggi daripada musim kemarau. Namun demikian, insidensi $V$. parahaemolyticus yang bersifat patogen lebih cenderung terjadi pada musim kemarau (bulan Oktober) ketika suhu air tambak $31,69^{\circ} \mathrm{C}$ dan $\mathrm{pH} 8,44$ (Tabel 5). Dibanding bulan lainnya, suhu air tambak di bulan Oktober merupakan suhu yang paling mendekati kondisi optimum $\left(37^{\circ} \mathrm{C}\right)$ untuk pertumbuhan bakteri V. parahaemolyticus (Lake, Hudson \& Cressey, 2003). Penelitian lain melaporkan bahwa V. parahaemolyticus berada pada semua lokasi di wilayah pantai Al Azziziah dan Half Moon (40/300; $13,3 \%$ ), dan kandungan $V$. parahaemolyticus yang tinggi terisolasi selama bulan Mei, Juni dan Juli ketika suhu air laut 30,31 , dan $33^{\circ} \mathrm{C}$ (ElHadi, 2012). Serupa dengan penelitian ini, sampel positif $V$. parahaemolyticus dari sampel udang yang berasal dari Laut Adriatik Utara dan Danau Venetia Utara, Italia terkonsentrasi di musim panas dan musim gugur (Juni-November 2012), tetapi juga terdeteksi pada bulan Maret dan Desember 2012. Pada periode Juli hingga Desember di samping memiliki prevalensi yang tinggi juga memiliki nilai MPN tertinggi dengan peningkatan hingga bulan September, dan menurun secara tetap hingga akhir tahun (Caburlotto et al., 2016). Sementara itu Lopez-Hernandez et al. (2015) melaporkan bahwa dari 80 sampel kerang yang berasal dari Mandinga Grande Lagoon dan Mandinga City (Mandiga lagoon system) Veracruz, Meksiko ditemukan sebanyak $62,5 \%$ V. parahaemolyticus tdh dan $12,5 \%$ $V$. parahaemolyticus trh. Prevalensi $V$. parahaemolyticus dengan gen $t d h+/ t r h-$ yang tinggi telah ditemukan selama musim dingin (dry season; April-Juni) dengan kisaran suhu $18,9-30,2^{\circ} \mathrm{C}$ sebesar $8,33 \%$. Prevalensi $V$. parahaemolyticus dengan gen $t d h+/ t r h+$ ditemukan selama musim semi (dry season) sebesar 0,42\%.

Sementara itu, sejumlah besar isolat V. parahaemolyticus yang ditemukan di musim hujan (bulan Februari dan Maret) tidak bersifat patogen. Sebaliknya di musim kemarau (bulan Oktober) ditemukan sejumlah kecil isolat $V$. parahaemolyticus yang bersifat patogen. Pada bulan Oktober terdapat $3,23 \%$ isolat $V$. parahaemolyticus dengan gen $t d h$ dan $1,61 \%$ dengan gen trh. Keduanya merupakan gen virulen yang menyebabkan $V$. parahaemolyticus menjadi bersifat patogen. Dilaporkan bahwa tidak semua strain $V$. parahaemolyticus menyebabkan penyakit, akan tetapi yang dapat menimbulkan penyakit pada umumnya berhubungan dengan keberadaan faktor TDH dan TRH. Miyamoto et al., (1969) menyebutkan virulensi $V$. parahaemolyticus lebih dekat hubungannya dengan TDH. $V$. parahaemolyticus memiliki dua faktor virulen yaitu protein pembentuk pori TDH yang berkontribusi dalam penyebaran penyakit ke manusia, dan $\mathrm{TRH}$ yang memiliki peran yang sama dengan TDH terhadap patogenesis penyakit. Selain itu bakteri $V$. parahaemolyticus juga mengkode sistem adhesi dan sekresi (T3SS1 dan T3SS2) yang membuatnya 


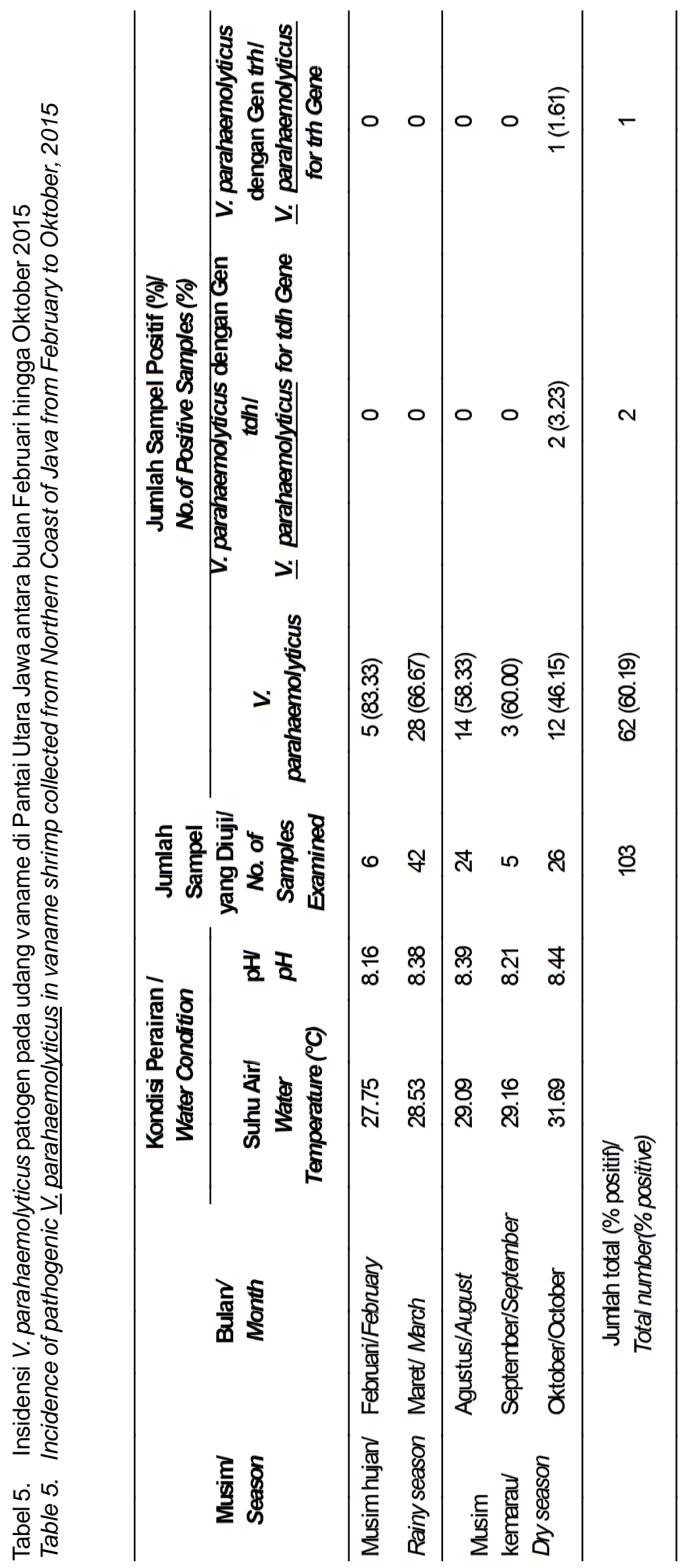


mampu bertahan pada kondisi lingkungan (Letchumanan, Chan \& Lee., 2014; Raghunath, 2015). Gen $t d h+$ jarang dijumpai pada isolat lingkungan, namun lebih sering ditemukan pada isolat klinis (Shirai et al., 1990). Beberapa strain membawa gene $t d h$ dan trh, namun terjadinya kasus klinis lebih sering terjadi pada strain yang membawa gen $t d h$ dari pada gen trh (Okuda et al., 1997). Serupa dengan hal ini, Saito et al. (2015) menyebutkan bahwa TRH berperan sebagai faktor patogenisitas, namun virulensi trh mungkin lebih rendah daripada $t d h$. Dilaporkan sebanyak 330 $(89,4 \%)$ outbreaks dan kasus infeksi sporadis $V$. parahaemolyticus yang terjadi di negara Jepang disebabkan oleh strain $t d h+/ t r h-$, sedangkan frekuensi infeksi yang disebabkan oleh strain tdh-/trh+ hanya sebesar 1,2\%. Sementara Leoni, Talevi, Masini, Ottaviani, dan Rocchegiani (2016) melaporkan bahwa gen trh+ ditemukan pada semua isolat yang berasal dari lingkungan dan pangan. Berdasarkan analisis sekuens asam amino pada sampel lingkungan dan pangan ditemukan adanya perbedaan sekuens asam amino trh2 isolat lingkungan dengan isolat klinis.

Berdasarkan Tabel 6, pada beberapa lokasi, insidensi $V$. parahaemolyticus yang lebih tinggi terjadi pada musim hujan (Feb-Maret), seperti yang terjadi di Karawang, Pulosari Brebes, Paciran Sidoarjo, Desa Jenu Tuban 1 dan Desa Gresik Harjo Tuban. Sebaliknya di lokasi lain seperti Indramayu insidensi $V$. parahaemolyticus yang lebih tinggi justru terjadi pada musim kemarau (Agustus-September). Namun frekuensi $V$. parahaemolyticus yang tinggi juga dapat terjadi pada kedua musim seperti yang terjadi di Randusanga Brebes, Brondong Lamongan dan Desa Jenu Tuban. Pada Tabel 6 terlihat bahwa

Tabel 6. Distribusi dan frekuensi terjadi $V$. parahaemolyticus pada sampel udang berdasarkan musim Table 6. Distribution and frequency of the occurrence of $\underline{V}$. parahaemolyticus from fresh shrimp samples based on season

\begin{tabular}{|c|c|c|}
\hline \multirow{2}{*}{$\begin{array}{l}\text { Lokasi// } \\
\text { Location }\end{array}$} & \multicolumn{2}{|c|}{$\begin{array}{l}\text { V. parahaemolyticus positif/ } \\
\text { Positive V. parahaemolyticus }\end{array}$} \\
\hline & $\begin{array}{c}\text { Musim Hujan/ } \\
\text { Rainy Season (\%) }\end{array}$ & $\begin{array}{l}\text { Musim Kemarau/ } \\
\text { Dry Season (\%) }\end{array}$ \\
\hline Indramayu 1 & $5 / 6(83.33)$ & - \\
\hline Indramayu 2 & - & $7 / 7(100.00)$ \\
\hline Karawang 1 & $6 / 8(75.00)$ & 4/12 (33.33) \\
\hline Pulosari Brebes & $2 / 4(50.00)$ & - \\
\hline Randusanga Brebes 1 & $4 / 4(100.00)$ & - \\
\hline Randusanga Brebes 2 & - & $1 / 1(100.00)$ \\
\hline Limbangan Wetan 1 & $0 / 2(0.00)$ & - \\
\hline Limbangan Wetan 2 & - & $1 / 2(50.00)$ \\
\hline Limbangan Kulon & - & $1 / 2(50.00)$ \\
\hline Paciran 1 Sidoarjo & $4 / 5(80.00)$ & - \\
\hline Paciran 2 Sidoarjo & - & $3 / 5(60.00)$ \\
\hline Brondong 1 Lamongan & $1 / 2(50.00)$ & $1 / 3(33.33)$ \\
\hline Brondong 2 Lamongan & $5 / 7(71.43)$ & $3 / 4(75.00)$ \\
\hline Brondong 3 Lamongan & - & $1 / 5(20.00)$ \\
\hline Ds Jenu 1 Tuban & $2 / 2(100.00)$ & $3 / 4(75.00)$ \\
\hline Ds Jenu 2 Tuban & $1 / 2(50.00)$ & $3 / 4(75.00)$ \\
\hline Ds Gesikharjo Tuban & $3 / 4(75.00)$ & $1 / 6(16.67)$ \\
\hline Jumlah sampel/No. of samples & 48 & 55 \\
\hline $\begin{array}{l}\text { Prevalensi V. parahaemolyticus / } \\
\text { Prevalence of } \underline{V} \text {. parahaemolyticus (\%) }\end{array}$ & $33 / 48(66.67)$ & 29/55 (52.73) \\
\hline
\end{tabular}




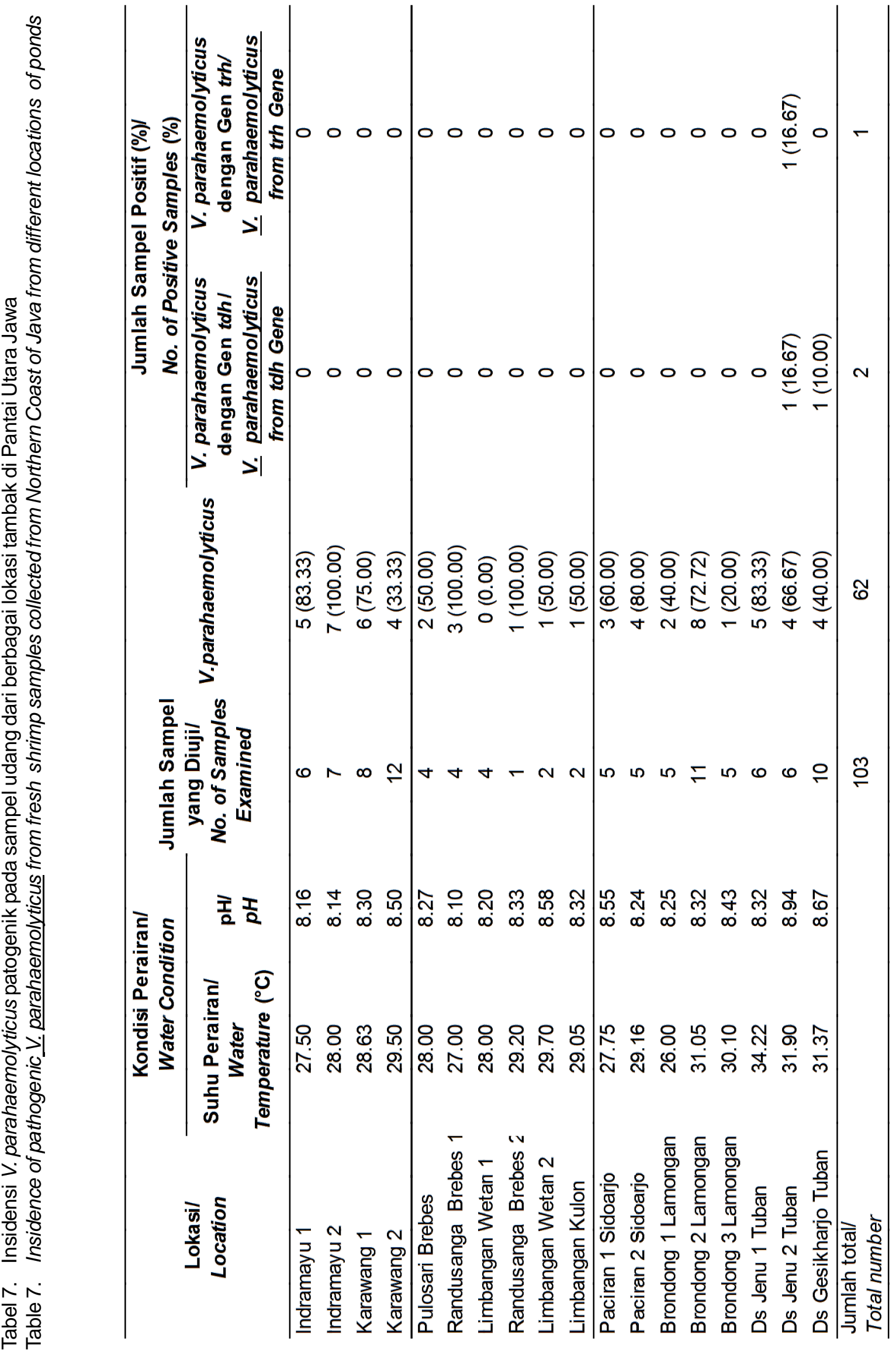


V. parahaemolyticus dijumpai hampir di setiap lokasi baik pada musim hujan maupun kemarau. Keberadaan V. parahaemolyticus pada setiap musim mengindikasikan bahwa bakteri ini merupakan spesies endemi pada daerah tersebut (Lopez-Hernandez et al., 2015).

Sampel udang dengan kandungan $V$. parahaemolyticus yang bersifat patogen ditemukan di dua lokasi tambak di wilayah Jawa Timur (Tabel 7) yang diindikasikan dengan ditemukannya gen $t d h$ dan trh.

Pada penelitian ini suhu air tambak berada pada kisaran yang mampu mendukung pertumbuhan bakteri $V$. parahaemolyticus, sementara $\mathrm{pH}$ perairan pada kondisi optimum, yaitu berturut-turut sebesar 27,75 $31,69^{\circ} \mathrm{C}$ dan $8,16-8,44$. Menurut Lake et al. (2003) pertumbuhan bakteri $V$. parahaemolyticus terjadi pada kisaran suhu $5-43^{\circ} \mathrm{C}$, namun pertumbuhan yang sangat cepat terjadi pada kondisi optimum (suhu $37^{\circ} \mathrm{C}$ ). Sedangkan $\mathrm{pH}$ optimum $V$. parahaemolyticus adalah 7,8 - 8,6 (Lake et al.). Sumber lain menyebutkan bahwa keberadaan bakteri berkaitan dengan suhu perairan, sehingga beberapa tidak terdeteksi hingga suhu perairan mencapai $19-20^{\circ} \mathrm{C}$ (Jay, 2000).

Dari 62 sampel positif $V$. parahaemolyticus yang dianalisis dengan metode PCR, ditemukan sebanyak 2 sampel positif $t d h$ dan 1 sampel positif trh. Kedua sampel positif $t d h$, masing-masing dengan insidensi $16,67 \%$ dan $10 \%$ (Tabel 7). Adanya gen tdh dan trh pada sampel udang tambak tersebut menjadi indikasi potensi patogenik dari $V$. parahaemolyticus (LopezHernandez et al., 2015). Dengan kata lain ketiga sampel tersebut mengandung gen virulen sehingga berisiko menimbulkan penyakit. Berdasarkan hasil pengamatan di lapangan, sampel udang yang terindikasi mengandung gen virulen tersebut berasal dari tambak udang yang sebagian udangnya mengalami penyakit white feces. Hal ini terlihat dari ukuran udang yang kecil meskipun telah berumur lebih dari 90 hari. Angka prevalensi ini relatif lebih tinggi dibandingkan Amizar (2011) yang menyebutkan bahwa dari produk seafood (udang, kerang dan kepiting) asal kota Padang, Sumatera Barat dan Muara Angke,(Jakarta) ditemukan adanya $V$. parahaemolyticus dengan total persentase gen toxR pada udang kelong (Penaeus indicus) sebesar 30\%, udang rebung (Metapanous endeavori) 26,7\%, kepiting katam (Scylla serrata) $61,1 \%$ dan sebesar $45 \%$ pada kerang hijau (Mytillus viridis). Namun dari 95 isolat yang positif toxR tidak ditemukan satupun gen virulen tdh dan trh.

Berbeda dengan Zulkifli et al. (2009) yang menyebutkan bahwa seluruh sampel kerang yang berasal dari Perairan Padang, Sumatera Barat memperlihatkan hasil negatif untuk gen $t d h$ dan $t r h$, maka prevalensi $V$. parahaemolyticus dengan gen $t d h$ dan trh pada penelitan ini cukup besar yakni mencapai $3,23 \%$ dan $1,61 \%$. Laporan lain menyebutkan terdapat 2,1\% dari sampel udang di Iran terinfeksi Vibrio spp. (Hosseini, Cheraghali, Yalfani \& Razavilar, 2004) dan sebanyak $1 / 122(0,88 \%)$ dari $8 / 122(6,55 \%)$ sampel air dan seafood yang berasal dari perairan Tunisia positif mengandung gen $t d h$ dan trh (Khouadja et al., 2013). Hal ini berarti bahwa prevalensi $V$. parahaemolyticus dengan gen virulen pada sampel udang Indonesia yang berasal dari tambak wilayah Jawa Timur sedikit lebih tinggi daripada seafood yang berasal dari Iran dan Tunisia. Adanya $V$. parahaemolyticus yang bersifat patogen pada sampel udang ini berisiko bagi kesehatan masyarakat terutama jika dikonsumsi dalam kondisi mentah. Chatterjee, Neogy dan Gorbach (1970) melaporkan bahwa sekitar $10 \%$ dari kasus gastroenteritis pada pasien di rumah sakit penyakit infeksi di Kolkata India disebabkan oleh V. parahaemolyticus. Dalam hal ini seafood seharusnya disajikan matang sebelum dikonsumsi, selain itu diperlukan pengawasan kualitas yang baik dalam hal budidaya, proses pengolahan, panen, dan konsumsi untuk menjamin kesehatan masyarakat (Adebayo et al., 2011).

\section{KESIMPULAN}

Keberadaan $V$. parahaemolyticus total dan patogenik pada udang tambak yang berasal dari Pantai Utara Jawa melalui deteksi gen toxR, tdh dan trh menunjukkan bahwa dari 103 sampel yang diuji diperoleh 62 sampel positif $V$. parahaemolyticus $(63,27 \%)$. Terdapat 2 sampel positif $t d h(3,23 \%), 1$ sampel positif trh $(1,61 \%)$ dan 1 sampel positif $t d h$ dan trh $(1,61 \%)$ yang berasal dari tambak wilayah Jawa Timur. Dengan demikian udang vaname segar yang berasal dari tambak wilayah Jawa Timur mengandung V. parahaemolyticus patogen sehingga berpeluang menimbulkan risiko bagi kesehatan.

\section{DAFTAR PUSTAKA}

Abu, G. \& Egenonu, C. (2008). The current status of the new Calabar river in the Niger Delta region of Southern Nigeria : a survey of antibiogram profiles of its bacterial isolates. African J. Environmental Science and Technol., 2(6), 134-141.

Adebayo-Tayo, B. C., Okonko, M. O., John, N. N., Odu, J., Nwanze, C., \& Ezediokpu, M. N. (2011). Occurrence of Potentially Pathogenic Vibrio Species in Sea Foods Obtained from Oron Creek. Advances in Biological Research, 5(6), 356-365. 
Amizar, R. (2011). Karakterisasi molekuler dari $V$. parahaemolyticus dan V. Cholerae yang diisolasi dari seafood (udang, kerang dan kepiting) asal kota Padang, Sumatera Barat dan Muara Angke, Jakarta Utara. Artikel. Program Pasca Sarjana Universitas Andalas Padang. 24p.

Annick, R. P., Alain, G., \& Fournier, J.M. (2002). Usefulness of $\mathrm{R} 72 \mathrm{H}$ PCR assay for diferentiation between $V$. parahaemolyticus and Vibrio alginolyticus species:validation by DNA^DNA hybridization. FEMS Microbiology Letters, 215, 1-6.

Badan Standarisasi Nasional (BSN). (2006). SNI 012332.5-2006. Cara uji mikrobiologi Bagian 5. Penentuan Vibrio parahaemolyticus pada produk perikanan. $27 \mathrm{p}$.

Bhunia, A.K. (2008). Foodborne Microbial pathogens: Mechanism and pathogenesis. Food Science Text Series. Springer.276 p.

Broberg, C. A., Calder, T. J., Orth, K. (2011). Review Vibrio parahaemolyticus cell biology and pathogenicity determinants. Microbes and Infection, 13, 992-10.

Caburlotto, G., Suffredini, E., Toson, M., Fasolato, L., Antonetti, P., Zambon, M., \& Manfrin, A. (2016). Occurrence and molecular characterisation of $V$. parahaemolyticus in crustaceans commercialised in Venice area, Italy. International Journal of Food Microbiology, 220, 39-49.

Ceccarelli, D., Hasan, N. A., Huq, A., \& Colwell, R. R. (2013). Distribution and dynamics of epidemic and pandemic Vibrio parahaemolyticus virulence factors. Frontiers in Cellular and Infection Microbiology, 3(97), 1-9.

Centre for Health Protection. (2010). Scientific Committee on Enteric Infections and Foodborne Diseases Food Poisoning Associated with $V$. parahaemolyticus in Hong Kong-Current Situation and Recommendations. Department of Health for Disease Prevention and Control. $15 \mathrm{p}$.

Chatterjee, B. D., Neogy, K. N., \& Gorbach, S. L. (1970). Study of Vibrio parahaemolyticus from cases of diarrhea in Calcutta. Indian J. Med Res., 58, 235239.

Chitov, T., Wongdao, S., Thatum, W., Puprae, T., \& Sisuwan, P. (2009). Occurrence of potentially pathogenic Vibrio species in raw, processed, and ready-to-eat seafood and seafood products. Maejo Int. J. Sci. Technol., 3(01), 88-98.

DePaola, A., Kaysner, C.A., Bowers, J.C., \& Cook, D.W. (2000). Environmental investigations of Vibrio parahaemolyticus in oysters following outbreaks 83 in Washington, Texas, and New York (1997 and 1998). Appl. Environ. Microbiol., 66, 4649-4654.

Dewanti-Hariyadi, R., Suliantari, Nuraida, L., \& Fardiaz, S. (2002). Determination of contamination profiles of human bacterial pathogens in shrimp obtained from Java, Indonesia. Proceedings of a Final Research Coordination Meeting held in Mexico City, Mexico, 2226 July 2002. Mexico: IAEA-Tecdoc-1431. 475 p.

Elhadi, N. (2012). Occurence of potentially human pathogenic Vibrio species in the coastal water of the eastern province of Saudi Arabia. Research Journal of Microbiology, 8(1), 1-4. doi: 10.3923/jm.2013.1.12.

Felix, F., Nugroho, T.T., Silalahi, S., \& Octavia, Y. (2011). Skrining bakteri Vibrio sp. asli Indonesia sebagai penyebab penyakit udang berbasis tehnik $16 \mathrm{~S}$ ribosomal DNA. Jurnal IImu dan Teknologi Kelautan Tropis, 3(2),85-99.

Food and Drug Administration (FDA). (2000). Draft Risk Assessment on the Public Health Impact of $V$. parahaemolyticus in Raw Molluscan Shellfish. December, 2000. 193 p.

Food and Drug Administration (FDA). (2015). BAM Appendix 2 : Most Probable Number from serial dilution. Retrieved from http://www.fda.gov/Food/ FoodScienceResearch/ Laboratory Methods/ ucm 109656.htm.

Hara-Kudo, Y., Sugiyama, K., Nishibuchi, M., Chowdhury, A., Jun Yatsuyanagi, J., Ohtomo, Y., Saito, A., Nagano, N.,Nishina, T., Nakagawa, H., Konuma, H., Miyahara, M. \& Kumagai, S. (2003). Prevalence of pandemic thermostable direct haemolysin producing $V$. parahaemolyticus O3:K6 in seafood and the coastal environment in Japan. Applied and Environmental Microbiology, 69, 3883-3891.

Hosseini, H., Cheraghali, A.M., Yalfani, R., \& Razavilar, V. (2004). Incidence of Vibrio spp. in shrimp caught off the south coast of Iran. Food Control,15, 187-190.

Jay, J.M. (2000). Modern Food Microbiology. 6th edn. In J, Sesma (Ed), (pp. 549-552). Maryland: Aspen Publishers, Inc.

Katadata KKP. (2016). Indonesia raja udang ASEAN. Retrieved from http://www.m.katadata.co.id/infografik/ 2016/03/30/indonesia raja.

Khouadja, S., Suffredini, E., Spagnoletti, M., Croci, L., Colombo, M. M., \& Amina, B. (2013). Presence of pathogenic $V$. parahaemolyticus in waters and seafood from the Tunisian Sea. World J Microbiol Biotechnol, 29,1341-1348.

Kim, Y.B., Okuda, J., Matsumoto, C., Takahashi, N., Hashimoto, S. \& Nishibuchi, M. (1999). Identification of $V$. parahaemolyticus strains at the species level by PCR targeted to the tox $R$ gene. Journal of Clinical Microbiology, 37, 1173-1177.

Lake, R., Hudson, A. \& Cressey, P. (2003). Risk profile: V. parahaemolyticus in seafood. Institute of Environmental Science and Research Ltd, Christchurch, New Zealand. 47 p.

Leoni, F., Talevi, G., Masini, L., Ottaviani, D., \& Rocchegiani, E. (2016). Trh (tdh"/trh+) gene analysis of clinical, environmental and food isolates of $V$. parahaemolyticus as a tool for investigating patho genicity. International Journal of Food Microbiology, 225, 43-53.

Lesmana, M., Subekti, D., Simanjuntak, C.H., Tjaniadi, P., Campbell J.R.,\& Oyofo B.A. (2001). Vibrio parahaemolyticus associated with cholera-like diarrhea among patients in North Jakarta, Indonesia. Diagn Microbiol Infect Dis., 39(2), 71-5.

Letchumanan, V., Chan, K., \& Lee, L. (2014). Vibrio parahaemolyticus : are view on the pathogenesis, 
prevalence, and advance molecular identification techniques. Frontiers in Cellular and Infection Microbiology, 5, 705

Linda, N.W. \& Asim, K.B. (2006). Detection of $V$. parahaemolyticus in Shellfish by Use of Multiplexed Real-Time PCR with TaqMan Fluorescent Probes. Applied and Environmental Microbiology, 72, 20312042.

López-Hernández, K.M., Pardío-Sedas, V.T., LizárragaPartida, L., de J. Williams, J., Martínez-Herrera, D., Flores-Primo, A., Uscanga-Serrano, R., \& Karla Rendón-Castro, K. (2015). Environmental parameters influence on the dynamics of total and pathogenic Vibrio parahaemolyticus densities in Crassostrea virginica harvested from Mexico's Gulf coast. Marine Pollution Bulletin, 91, 317-329.

Marlina, Radu, S., Kqueen, C.Y., Napis, S., Zakaria, Z., Mutalib, S.A., \& Nishibushi, M. (2007). Detection of $t d h$ and trh genes in Vibrio parahaemolyticus isolated from Corbicula moltkiana prime in West Sumatera, Indonesia. Southeast Asian Journal of TropicalMedicine and Public Health, 38(2), 349-355.

Merward, A. M. A., El-Ghareeb, W.R., \& Taisir, S.M. (2011). Occurence of some zonotic Vibrios in shellfish and Diarrheic patients with regard to $t d h$ gene in $V$. parahaemolyticus. J. American Sci., 7(9), 449-459.

Miyamoto, Y., Kato, T., Obara, Y., Akiyama, S., Takizawa, K. \& Yamai, S. (1969). In vitro hemolytic characteristic of $V$. parahaemolyticus: its close correlation with huma pathogenicity. Journal of Bacteriology, 100, 1147-1149.

Nelapati, S., \& Krishnaiah, N. (2010). Detection of total and pathogenic $V$. parahaemolyticus by polymerase chain reaction using tox $R$, Tdh and trh genes. Veterinary World, 3(6), 268-271.

Newton, A., Kendall, M., Vugia, D. J., Henao, O. L., \& Mahon, B.E. (2012). Increasing rates of vibriosis in the United States,1996-2010: review of surveillance data from 2 systems. Clin. Infect.Dis, 54, S391-S395. doi:10.1093/cid/cis243.

Nishibuchi, M., \& Kaper, J.B. (1995). Thermostable direct hemolysin gene of $V$. parahaemolyticus: a virulence gene acquired by a marine bacterium. Infect Immun, 63(6), 2093-2099.

Okuda, J., Ishibashi, M., Hayakawa, E., Nishino, T., Takeda, Y., Mukhopadhyay, A.K., Garg, S., Bhattacharya, S.K., Nair, G.B., \& Nishibuchi, M. (1997). Emergence of a unique 03: K6 clone of $V$. parahaemolyticus in Calcutta, India, and isolation of strains from the same clonal group from Southeast Asian travelers arriving in Japan. J Clin Microbiol., 35(12), 3150-3155.

Pal, D., \& Das, N. (2010). Isolation, identification and molecular characterization of $V$. parahaemolyticus from fish samples in Kolkata. European Review for Medical and Pharmacological Sciences, 14, 545-549.

Raghunath, P. (2015). Roles of thermostable direct hemolysin (TDH) and TDH-related hemolysin (TRH) in Vibrio parahaemolyticus. Frontiers in Cellular and Infection Microbiology, 5(805), 1-4.
Ronald, G.L., \& Santos, G. (2001). Guide to foodborne pathogens. New York: John Wiley and Sons, Inc. 373p.

Saito, S., Iwade, Y., Tokuoka, E., Nishio, T., Otomo, Y., Araki, E., Konuma, H., Nakagawa, H.,Tanaka, H., Sugiyama, K., Hasegawa, A., Sugita-Konishi, Y., \& Hara-Kudo, Y., (2015). Epidemiological evidence of lesser role of thermostable direct hemolysin (TDH)related hemolysin ( $\mathrm{TRH}$ ) than $\mathrm{TDH}$ on Vibrio parahaemolyticus pathogenicity. Foodborne Pathog. Dis., 12, 131-138.

Shah. P. D., \& Deokule, J. S. (2006). Isolation of Vibrio mimicus from a case of acute diarhea - a case report. Indian Journal of Pathology and Microbiology, 49, 455-456.

Shirai, H., Ito, H., Hirayama, T., Nakamoto, Y., Nakabayashi, N., Kumagai, K., Takeda, Y., \& Nishibuchi, M. (1990). Molecular epidemiologic evidence for association of thermostable direct haemolysin $(T D H)$ and $T D H$-related haemolysin of $V$. parahaemolyticus with gastroenteritis. Infection and Immunity, 58(11), 3568-3573.

Sunorita, M., \& Tjarsono, I. (2014). Kebijakan Hambatan Non Tarif Di Pasar Uni Eropa Terhadap Ekspor Komoditas Udang Indonesia. Jurnal Transnasional, 6(1) :-

Tada, J., Ohashi, T., Nishimura, N., Shirasaki, Y., Ozaki, H., Fukushima, S., Takano, J., Nishibuchi, M. And Takeda, Y. (1992). Detection of thermostable direct hemolysin gene $(t d h)$ and thermostable directrelated hemolysin gene (trh) of $V$. parahaemolyticus by polymerase chain reaction. Molecular and Cellular Probes, 64, 477-487.

Thomspon, F.L., Lida, T., \& Swings, J. (2004). Biodiversity of vibrios. Microbiol. Mol. Biol. Rev., 68, 403-431.

Tiruvayipati, S., Bhassu., Kumar, N., Baddam, R., Shaik, S., Gurindapalli, A. K., Lin Thong, K., \& Niyaz Ahmed, N. (2013)..Genome anatomy of the gastrointestinal pathogen, $V$. parahaemolyticus of crustacean origin. Gut Pathogens, 5, 37.

Vieira, R. H. S. F., Costa, R. A., Menezes, F. G. R., \& Maggioni, R. (2011). Kanagawa-Negative, $t d h$ - and trh-Positive Vibrio parahaemolyticus Isolated from Fresh Oysters Marketed in Fortaleza, Brazil. Curr Microbiology, 63,126-130. doi: 10.1007/s00284-0119945-x.

Wong, H.C., Chen, M.C., Liu, S.H., \& Liu, D.P. (1999). Incidence of highly genetically diversified Vibrio parahaemolyticus in seafood imported from Asian countries. Int. J. Food Microbiol., 52, 181-188.

Yang, Z., Jiao, X., Zhou, X., Cao, G., Fang, W., \& Gu, R. (2008). Isolation and molecular characterization of Vibrio paraheamolyticus from fresh, low temperature preserved, dried and salted seafood products in two coastal areas of eastern China.International of food Microbiol., 125, 279-285.

Yennie, Y., Hariyadi, R.D., \& Poernomo, A. (2015). Prevalensi gen tdh dan th Vibrio parahaemolyticus pada udang vaname (Litopenaeus vannamei) di wilayah Indramayu, Jawa Barat. JPB Kelautan dan Perikanan, 10 (1), 61-70. 
Yoder, J.S., Hlavsa, M.C., Craun, G.F., Hill, V., Roberts, V., Yu, P.A., Hicks, L.A., Alexander, N.T., Calderon, R.L., Roy, S. L and Beach, M. J. (2008). Surveillance for waterborne diseases and outbreaks associated with recreational water use and other aquatic facility associated health events-United State 2005-2006. MMWR Surveillance Summaries, 57, 1-29.
Zulkifli, Y., Alitheen, N.B., Son, R., Yeap, S.K., Lesley, M.B. \& Raha, A.R. (2009). Identification of V.parahaemolyticus isolates by PCR targeted to the tox $\mathrm{R}$ gene and detection of virulence genes. International Food Research Journal, 16, 289-296. 